\title{
Characteristics of Buginese Traditional Houses and their Response to Sustainability and Pandemics
}

\author{
Mustamin Rahim ${ }^{1 *}$ and Irwan Abbas $^{2}$ \\ ${ }^{1}$ Department of Architecture, Khairun University, Gambesi Campus 97719, Ternate City, Indonesia \\ ${ }^{2}$ Department of Pancasila and Civic Education, Khairun University, Akehuda Campus 97735, Ternate City, Indonesia
}

\begin{abstract}
This study aims to analyze the characteristics of traditional Buginese houses and positive features that are beneficial to response sustainability and pandemics through literature studies and field observations. The study results show that the traditional Buginese houses were built based on local wisdom and environmental consideration from the philosophy of "Sulapa Eppa" (rectangular) with the meaning "Universe". The building typology is a stilt house consisting of three levels of the room, which symbolize the human body anatomy; head (roof/house attic), body (body-house), and foot (under the house). The Buginese traditional architecture is very responsive to nature and sustainability and contains positive features in maintaining the building occupant's health in the past according to experience and resources at that time. These positive values can inspire sustainable designs in the future.
\end{abstract}

Keywords: Traditional Buginese houses, Local wisdom,Ssustainability and pandemics

\section{Introduction}

Indonesian traditional architecture grows and develops by following local wisdom and culture [1]. The characteristics of traditional houses differ in each region according to regional conditions and local culture. Traditional architecture is rich in traditional forms, technologies, and meanings [2]. The architecture reflects the lifestyle and culture of the people [3]. Humans adapt to the conditions of the surrounding environment. The form of adjustment is reflected in the characteristics of the dwelling. The rules of houses construction are agreed upon in community or tribal groups according to local culture. Spatial form and layout are the results of shared thinking, which is influenced by culture, technology, available materials, climate, and construction techniques [4]. As long as these local techniques are considered up to date and can solve problems in the next generation, the local rules and techniques will still be used by adjusting to the developments and challenges of the times [5].

Traditional houses are one of the many valuable properties, especially in terms of history, customs, culture, and architectural characteristics. The culture and local wisdom of the Buginese in South Sulawesi have distinctive features and characters that are different from other tribes in Indonesia, one of them is the traditional house. The shape of the house and its structure reflect the Buginese view of the spatial layout of the universe (macrocosm) and human life. In the tradition of construction houses, the role of Sanro Bola (spiritual master of the traditional house) is very important because knowledge and experience have been passed down from their ancestors [6-7] so that cultural values and philosophy are very strong in the tradition of the construction process of the Buginese houses [8]. The construction process is full of local wisdom that is in harmony with nature so that indirectly, it has an impact on the harmony and health of humans, environment, and resources [3]. However, the characteristics of regional architecture have shifted due to the hegemony of urban development [9]. Therefore, the preservation of traditional architectural works is very important and beneficial for future generations. According to Sundarraja [10] that the study of traditional architecture provides useful insights into contemporary architectural design.

Architectural works are intended to improve the quality of human life. As part of the natural environment, quality improvement should not only concern the needs of occupants but also improve the quality of the surrounding environment [3]. Several previous studies have shown that traditional architecture contains sustainable features [11-13]. According to Petrasincu [14] that traditional architecture uses a bioclimatic building strategy in responding to climatic conditions. Traditional houses in the tropics refer to a passive solar strategy by maximizing natural lighting and ventilation to achieve indoor thermal comfort [15].

* Corresponding author : mustamin_rahim@yahoo.co.id 
Characteristics, elements, styles, and expressions of traditional architecture can inspire contemporary architecture [16]. However, some researchers consider traditional architecture to be of low quality and not suitable for the development of modern architecture [1719]. Therefore, this study will investigate local wisdom in Buginese traditional houses and analyze positive features that are useful in increasing sustainability insights in the future according to tropical climate conditions.

\section{Methodology}

This research is qualitative research through literature study, field observations, and interviews as conducted by several previous researchers [20-23] to find out local wisdom in the Buginese traditional architecture in South Sulawesi, Indonesia and analyze sustainable features in response to tropical climate conditions and improve occupant health. The data were analyzed descriptively and architecturally to understand building typology and philosophy, orientation, spatial patterns, and building ornaments. Sustainability features were analyzed using USGBC assessment method. According to the United States Green Building Council (USGBC) [24] that sustainability can be achieved through several aspects as follows: location and transportation, sustainable sites, water efficiency, energy and atmosphere, materials and resources, and indoor air quality.

\section{Result and Discussion}

\subsection{Building Philosophy}

Buginese houses are built based on a "cosmic balance" view. The Buginese view is that the universe is rectangular (Sulapa Eppa). The philosophy of "Sulapa Eppa" (rectangular) means the four wind directions: east, west, north, and south, or the four elements of the universe: wind, water, earth, and fire. This philosophy is also reflected in the form of the site and shape of buildings. The house orientation is generally facing north and east. The north direction means the source of positive life and the east direction is a source of light. The shape of the rectangular plan is based on the view of the "Sulapa Eppa" form. The vertical and horizontal spatial patterns symbolize the human body's anatomy (Fig. 1). Vertically is a human standing position: roof (head), house-body (body), under the house (foot), while horizontally is in a lying position: front room (head), middle room (body), and backroom (Foot) [25].

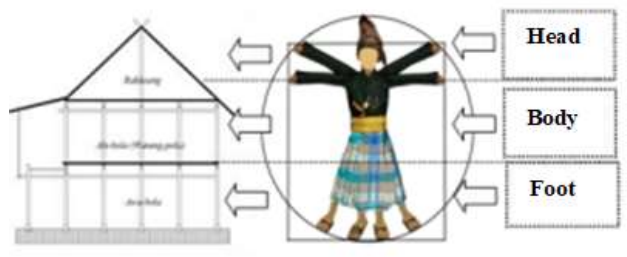

Fig. 1. Vertical Building Philosophy [27].

\subsection{Building Typology}

The Buginese house is a stilts house, which consists of three levels vertically, namely the upper room, middle room, and lower room. This is based on the view of the universe (macrocosm) consisting of three levels namely the upper realm (sky), middle realm (earth), and the underworld (ground). Buginese houses are generally not divided into several bedrooms but only consist of three main rooms, front room, middle room, and backroom. The main entrance or main staircase is located at the front of the house in the right or left edge of the housing body and there is a water barrel (Bempa) in the front of the stairs for washing hands and feet [26].

In addition, generally Buginese houses have additional room, namely (1) Lego-Lego is a room in front of the main house that functions as a lounge room or terrace room with a roof model that is similar to the roof of the main house in a smaller size. (2) Dapureng is a kitchen room, which located behind or beside the rear of the main building (Fig. 2). It is equipped with a ladder in front of the dapureng for easy accessibility. On Buginese house, there are parts of the house that contain sacred meanings, namely "Possi bola" and "Timpak laja". Possi bola is the central pillar in the center of the house as a source of "sumange" or spirit for residents, as a symbol of "harmony and blessings" in life. The level of the timpak laja symbolizes the social stratification of the occupants namely: 5 levels for the king's palace, 4 levels for nobles or former kings, 3 levels for descendants of nobility, 2 levels for the general public, and 1 level for slaves [27].

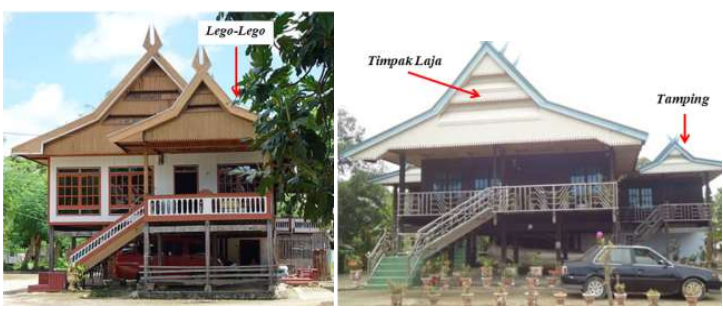

Fig. 2. Traditional Buginese House.

\subsection{Building Orientation}

The house orientation is very important and sacred in the Bugis society, usually, the house is oriented to the sun, mountains, rivers, sea, and wind direction [28]. The orientation of the house is influenced by the cosmological factors of society. Determination of house orientation is related to community beliefs such as house orientation on the fishing settlements in SalarangMaros, which is oriented to the east because it is influenced by cultural factors and beliefs in ancestral lands originating from Bone district [29] or based on traditional rules from generation to generation, where they believe that if they follow these rules, the blessings of life and sustenance will be abundant [28]. Another consideration relates to livelihoods such as Buginese houses in coastal areas, where houses are always oriented to the river and sea because it relates to their livelihoods as fishermen with settlement patterns are 
generally linear and clustered following river land conditions [30-31].

\subsection{Settlement Pattern}

Buginese settlement patterns are generally dense and spread out. The cluster pattern is mostly found in the lowlands, such as near rice fields, seafront, and lakes, while the spread pattern is mostly found in mountains or plantations. Buginese villages can be distinguished based on the workplace, namely: Pallaon-Rumah (farmer's village), Pakkaja (fishing village), and Matowa (village head). Initially, the ancient Buginese village was only a few houses, then it grew continuously due to the addition of family members to reach hundreds of houses. Those houses are generally lined up facing south or west, or with their backs to the river. The center of the old village is a sacred place (Possi tama), with a large banyan tree, and a house of worship (Saukang). In addition to sacred places, a village generally has a prayer room or mosque, a village market, and a cemetery [32].

\subsection{Space Pattern}

The vertical space pattern of the Buginese houses consists of 3 levels, namely (1) Rakeang (space under the roof), which functions as a logistics room for storing rice/ foodstuff, storing heirlooms and crafts, and also for weaving and makeup in ancient times. (2) Ale bola (House body) is the main part of the house as a space for the main activities of occupants: guest service, sleeping, eating, and other activities in managing daily life. (3) Awa bola (under the house) for storing livestock and farming or fishing equipment [25]. Horizontally, the division of house room in Bugis terms is called lontang or latte, which consists of 3 rooms: (1) Lontang ri saliweng (front room) is a semi-private room, which functions as guest service, guest bed, deliberation, store seeds, and a space to lay dead bodies before burial. (2) Lontang ritengngah (middle room) is a private room, serves as a bedroom of family heads and children who are not yet mature, space for eating and giving birth. (3) Lontang rilaleng (back room) is a very private room, which functions as a bedroom for girls and grandmothers/grandfathers.

\subsection{Building Ornament}

Bugis architectural decorations consist of flora, fauna, Arabic script or calligraphy, stars, and crescent moons. The ornamental variety of flora is in the form of "Parengreng" flowers, which means beautiful and interesting flowers. This flower spreads in the form of tendrils without breaking. Parenreng flower ornaments are found on window boards, main stairs, and ridge covers. This perengreng flower is likened to an unbroken fortune like the spread of the flower. Fauna ornaments: roosters, buffalo heads, and dragons are symbols of courage. This ornament is usually placed at the top of the house ridge. Ornaments in the form of calligraphy, crescent moon, and stars are found in religious buildings or kings' palaces. In addition, ornaments on the house-body (Ale Bola) are generally from floral motifs such as parenreng flowers, bamboo shoots, banana hearts, and geometric patterns, and other ornaments in the form of waves and stars motifs. These ornaments are usually placed on vents, walls, and windows [33].

\subsection{Response to Sustainability}

Sustainable development is divided into three interacting sectors: economic, environmental, and social [34-35]. Economic, environmental, social, and cultural sustainability is the fourth pillar of sustainable development [36]. Furthermore, the application of Sustainable development in the constitution of the Republic of Indonesia [37] on environmental management states that sustainable development with an environmental perspective is a conscious and planned effort, which integrates the environment including resources into the development process for ensuring the ability, welfare, and quality of life of present and future generations.

Table 1. Features of local wisdom and sustainability on the orientation of Buginese houses

\begin{tabular}{|c|c|c|}
\hline $\begin{array}{c}\text { Building } \\
\text { Orientation }\end{array}$ & Local Wisdom & $\begin{array}{c}\text { Sustainable } \\
\text { Features }\end{array}$ \\
\hline Mountain & $\begin{array}{l}\text { - Life expectancy } \\
\text { as high as a } \\
\text { mountain } \\
\text { - Beautiful } \\
\text { panorama }\end{array}$ & $\begin{array}{l}\text { - Water resource, life } \\
\text { souces } \\
\text { - Outdoor thermal } \\
\text { improvement } \\
\text { - Harmony with } \\
\text { nature }\end{array}$ \\
\hline Sunrise & $\begin{array}{l}\text { - East facing of the } \\
\text { house } \\
\text { - Source for a new } \\
\text { life }\end{array}$ & $\begin{array}{l}\text { - Maximizing natural } \\
\text { lighting and } \\
\text { ventilation } \\
\text { - Passive solar house } \\
\text { - Friendly to next } \\
\text { generation }\end{array}$ \\
\hline workplace & $\begin{array}{l}\text { - Controlling } \\
\text { gardens or rice } \\
\text { fields from the } \\
\text { home } \\
\text { - Controlling house } \\
\text { from the } \\
\text { workplace }\end{array}$ & $\begin{array}{l}\text { - Sustainable site } \\
\text { - Easy to control the } \\
\text { house and } \\
\text { workplace (smart } \\
\text { design concept) }\end{array}$ \\
\hline Main road & $\begin{array}{l}\text { - Easy access for } \\
\text { working } \\
\text { activities } \\
\text { - Social interaction } \\
\text { with neighbors }\end{array}$ & $\begin{array}{l}\text { - Ease of accessibility } \\
\text { - Indoor airflow } \\
\text { improvement } \\
\text { - Function as open } \\
\text { space } \\
\text { - Social sustainable }\end{array}$ \\
\hline River & $\begin{array}{l}\text { - Natural drainage: } \\
\text { drainage flows } \\
\text { backward of the } \\
\text { house } \\
\text { - Support to } \\
\text { fishing activity } \\
\text { - Boat mooring }\end{array}$ & $\begin{array}{l}\text { - Evaporation } \\
\text { improvement } \\
\text { around the river } \\
\text { - Natural drainage } \\
\text { improvement } \\
\text { - Sustainable river } \\
\text { transportation }\end{array}$ \\
\hline
\end{tabular}

Buginese houses are built with the philosophy of "Sulappa Eppa" which means "universe". It shows that Buginese traditional architecture respects natural values 
and environmental sustainability. The parts of the Buginese house are very close to natural elements (Tables 1 and 2).

Table 2. Sustainable features on the Buginese traditional architecture.

\begin{tabular}{|c|c|}
\hline $\begin{array}{c}\text { Sustainable } \\
\text { Aspects }\end{array}$ & $\begin{array}{l}\text { Sustainable } \\
\text { Features }\end{array}$ \\
\hline $\begin{array}{l}\text { Location and } \\
\text { transportation }\end{array}$ & $\begin{array}{l}\text { Orientation to the main road, } \\
\text { Easy accessibility for } \\
\text { working activities }\end{array}$ \\
\hline Sustainable sites & $\begin{array}{l}\text { Workplace surrounding area, } \\
\text { Following topographical } \\
\text { conditions in lowland and } \\
\text { mountain areas, adaptation to the } \\
\text { environmental condition }\end{array}$ \\
\hline Water efficiency & Well water and rainwater \\
\hline $\begin{array}{l}\text { Energy and } \\
\text { atmosphere }\end{array}$ & $\begin{array}{c}\text { Passive solar house } \\
\text { Natural ventilation and lighting }\end{array}$ \\
\hline $\begin{array}{l}\text { Materials and } \\
\text { resources }\end{array}$ & $\begin{array}{c}\text { Natural material } \\
\text { from surrounding area }\end{array}$ \\
\hline Indoor air quality & $\begin{array}{l}\text { Cross ventilation system } \\
\text { Vegetation for shading and } \\
\text { filter pollution }\end{array}$ \\
\hline
\end{tabular}

The philosophy of "Bempa" or water barrel in front of the Buginese house is one of the efforts in maintaining the cleanliness of the house and occupant's health. In the past, Bempa were always placed near the stairs of the Buginese house (Fig. 3) and everyone who would go up to the house (house on stilts) had to first wash their feet and hands to clean them from all dirt and sources of disease. This is an innovation of the Bugis society according to their level of understanding at that time in maintaining cleanliness to avoid disease. In addition, at the front or side of the Buginese house in the past, there was a well or water reservoir and a bathroom so that every occupant comes home from the garden or workplace they were always cleaned their body or takes a shower before entering the house.
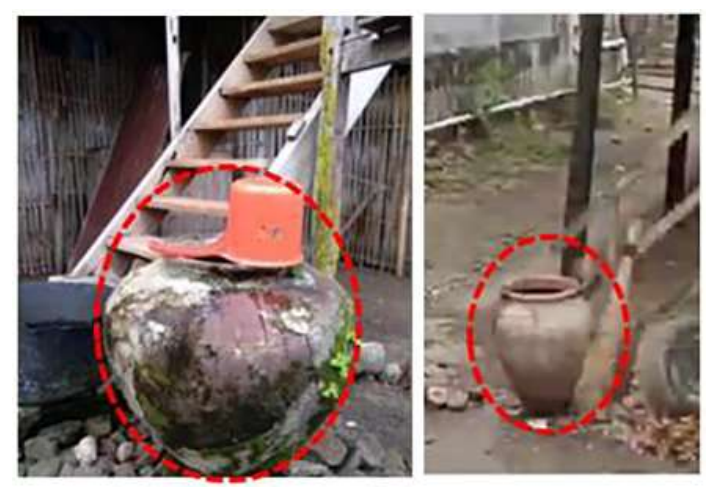

Fig. 3. Traditional Hand-Washing of Buginese (Bempa).
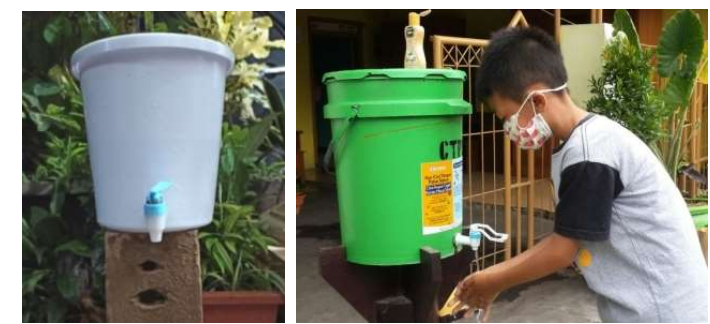

Fig. 4. COVID-19 Hand-Washing.

The culture of hand washing has been an important part of the life of the Bugis Society since ancient times, but this culture has been eroded with the development of modern times. The emergence of the covid pandemic since December 2019 requires following the coronavirus prevention protocol for reducing transmission, one of them is the "hand-washing" protocol (Fig. 4). According to [38-40] that washing hands properly is one of the essential preventions to reduce Covid-19 transmission. According to [25] that philosophy of "Bempa" in front of the Buginese house can be an inspiration for providing a sterilization room in the building with the functions as a transition room between outdoor and indoor for sensors of health conditions, washing hands, sterilizing clothes before entering the workspace or main room.

\subsection{Conclusion}

Buginese traditional houses were built based on local wisdom and environmental considerations from the philosophy of "Sulapa Eppa" (rectangular) with the meaning of "universe". The Buginese house is in the form of a stilt house consisting of three levels vertically based on the view of the universe (macrocosm), namely the upper world (sky), the middle world (earth), and the underworld (ground). The space pattern symbolizes the human body anatomy, vertically: consist 3 levels: roof (head), house body (body), under the house (foot), and horizontally consists of three rooms, namely front room or living room (head), central room (body), Backroom (foot). Buginese traditional architecture can adapt to tropical climate conditions by passive solar design strategy with a wooden construction system. This study also found that the culture of handwashing has been an important part of the life of Bugis society since ancient times, where in each house there was a "Bempa" or water barrel in front of the house for washing hands and feet before entering the house. This local wisdom and positive features can inspire sustainable contemporary design after the pandemic.

We would like to express our sincere gratitude and appreciation to the Ministry of Education, Culture, Research, and Technology, the Republic of Indonesia, for providing the research fund.

\section{References}

[1] M. Soeroto. From Traditional Architecture to the National Architecture of Indonesia. Ghalia Indonesia Press, Jakarta (2003). 
[2] M. Rahim. Traditional Architecture of Moloku Kie Raha. Bina Ilmu Press, Surabaya (2019).

[3] B. Salgın, Ö. Bayram, A. Akgün, K. Agyekum. "Sustainable Features of Vernacular Architecture: Housing of Eastern Black Sea Region as a Case Study," Arts, J. 6 (4), 11 (2017).

[4] A. Rapoport. House Form and Culture. Englewood Cliffs, N.J.: Prentice Hall (1969).

[5]. Asquit, Felinga. Vernacular Architecture in the Twentynth Century. Taylor and Francis, London and New York (2006).

[6] A.J. Hatta, I. Sudradjat. "Peran sanro bola dalam tradisi membangun rumah tradisional Bugis di Kabupaten Soppeng," ARTEKS J. 5(1), 63-72 (2020).

[7] S. Syarif, A. Yudono, A. Harisah M.M. Sir. "Ritual Proses Konstruksi Rumah Tradisional Bugis di Sulawesi Selatan," Walasuji, 9(1), 53-72 (2018).

[8] Rosyadi. "Tradisi Membangun Rumah dalam Kajian Kearifan Lokal (Studi Kasus pada Masyarakat Adat Kampung Dukuh)." Patanjala J. 7(3): 15-30 (2015)

[9] Y. Li, Y. Zhu, L. Yu, Z. Bi, G. Huang. "Typology in Vernacular Architecture-Qianmo Tower Post Station in Mingyue Village," In E3S Web of Conferences (Vol. 237). EDP Sciences (2021).

[10] M. Sundarraja, S. Radhakrishnan, R. Priya. "Understanding Vernacular Architecture as a tool for Sustainability," $10^{\text {th }}$ National Conference on Technological Trends, Trivanduram (2009).

[11] B. Salgın, O.F. Bayram, A. Akgün, K. Agyekum. "Sustainable Features of Vernacular Architecture: Housing of Eastern Black Sea Region as a case study". Arts J. 6(3), 1-11 (2017).

[12] F. Convertino, S.Di Turi, P. Stefanizzi. "The Color in the Vernacular Bioclimatic Architecture in Mediterranean Region". Energy Procedia, 126, 211-218 (2017).

[13] Q. Liu, Z. Liao, Y. Wu, D.M. Degefu, Y. Zhang. "Cultural Sustainability and Vitality of Chinese Vernacular Architecture: A Pedigree for the Spatial Art of Traditional Villages in Jiangnan Region,” J. Sustainability, 11(6898), 1-27 (2019).

[14] N. Petrasincu, L. Fara. "Bioclimatic Elements for Traditional Romanian Houses," In PLEA Proc, 85-88 (2006).

[15] J. Victoria, S.A. Mahayuddin, W.A.Z.W. Zaharuddin, S.N. Harun, B. Ismail. "Bioclimatic Design Approach in Dayak Traditional Longhouse". Procedia Engineering, 180, 562-570 (2017).

[16] S.S. Dhepe, S. Valsson, S. "Traditional Approach Towards Contemporary design: A case study," J. Eng. Res. and App, 7(3), 12-22 (2017).

[17] J.E.P. Fernandes, R. Mateus, L. Bragança. "The Potential of Vernacular Materials to the Sustainable Building Design," In Vernacular Heritage and Earthen Architecture: Contributions for Sustainable Development - Correia. Carlos \& Rocha Eds, 625-629 (2014).

[18] P. Oliver. Built to Meet Needs: Cultural Issues in Vernacular Architecture. UK: Architectural Press, 21-27 (2006).
[19] A. Wahid. "Adaptive Vernacular Options for Sustainable Architecture," J Int Soc Study Vernac Settl, 2, 74-85 (2012).

[20] N. Akbar, I.R. Abubakar, A.S. Bouregh. "Fostering Urban Sustainability through the Ecological Wisdom of Traditional Settlements," Sustainability, 12(23), 10033 (2020).

[21] I.F. Ozorhon, G. Ozorhon. "Investigating the Ways of Learning from Vernacular Architecture," WIT Transactions on The Built Environment. WIT Press, 191, 421-429 (2019).

[22] I.G. Crespo, M.B. Barrera, L.M. Ramos. "Climatic Analysis Methodology of Vernacular Architecture," in Vernacular Architecture: Towards a Sustainable Future, Taylor \& Francis Group, London, 327-332 (2015).

[23] M. Rahim, M. Ibrahim, F. Marasabessy. (2021). "Construction System and Environment Adaptation of Traditional Architecture in Moluccas Island," Civil Eng. \& Arch. J. 9(5), 1530-1545 (2021).

[24] USGBC, T. "Green Building Design and Construction: With Global Alternative Compliance Paths,"

https://www.usgbc.org/sites/default/files/LEED $\% 202009 \% 20 R G \% 20 B D+C$-supplement GLOBAL_10_2014_Update.pdf (accessēe Sept. 10, 2021)

[25] Mattulada. Kebudayaan Bugis-Makassar (BugisMakassar Culture), in Koentjaraningrat, Dr., Manusia dan Kebudayaan di Indonesia. Sixth E. Djambatan (1981).

[26] M. Rahim. "Implikasi Covid-19 Terhadap Bangunan dan Lingkungan," SipilSains J. 11(1). (2021).

[27] S. Syarif. "Konstruksi Nilai-nilai Kearifan Lokal Arsitektur Tradisional Bugis Soppeng," Doctoral Thesis, Architecture Depart., Hasanuddin University, Makassar, Indonesia (2020).

[28] I. Idawarni. "Penentuan Arah dan Letak Permukiman dan Rumah Tinggal Kaitannya dengan Kosmologi," Local Wisdom J. 3(1), 09-18 (2011).

[29] W. Wikantiri, Veronika, Marwah. (2011). "Faktor Penentu Orientasi Rumah di Permukiman Nelayan Dusun Salarang Kabupaten Maros," Proc. Universitas Hasanuddin, Makassar (2011).

[30] Nurjannah, Anisa. "Pola Permukiman Bugis di Kendari,” NALARs J. 9(2), 139-146 (2010).

[31] Hamka, Antariksa, L.D. Wulandari. Karakteristik Orientasi Rumah Tradisional Bugis (Bola Ugi). Langkau Betang J. 2(2) 2015.

[32] S. Rosyidah. Traditional Architecture Concept of House Bugis of with the Accomplishment of Dweller Requirement. Thesis, Universitas Hasanuddin, Makassar (2009).

[33] P.P. Yunus. "Makna Simbol Bentuk dan Seni Hias pada Rumah Bugis Sulawesi Selatan," Seni \& Budaya Panggung J., 22(3), 225 - 350 (2012).

[34] M. Rahim, A. Basri, H. Fauzi. "Identification of Construction System and Arrangement of Bajo Tribe Settlement based on Local Wisdom and 
Environmentally Friendly," Int. J. Geomate, 17(64), 261-266 (2019).

[35] M. Keiner. History, Definitions and Models of Sustainable Development. ETH Zürich (2005).

[36] UCLG. "Culture: Fourth Pillar of Sustainable Development," 3rd World Congress of UCLG, (2018).

[37] The Constitution of the Republic of Indonesia, UU No.23/1997.

[38] L. Cirrincione, F. Plescia, C. Ledda, V. Rapisarda, D. Martorana, R.E. Moldovan, E. Cannizzaro. "COVID-19 pandemic: Prevention and Protection measures to be Adopted at the Workplace," Sustainability, 12(9), 3603 (2020).

[39] D. Pradhan, P. Biswasroy, P.K. Naik, G. Ghosh, G. Rath. "A Review of Current Interventions for COVID-19 Prevention," Archives of Medical Research, 51(5), 363-374 (2020).

[40] M. Haque. Handwashing in Averting Infectious Diseases: Relevance to COVID-19. Pop. Ther. \& Cli. Phar. J. 27(SP1), e37-e52 (2020). 